\title{
Brexit: some implications for African higher Education
}

\author{
Patrício V. Langa, Patríck Swanzy and David Law
}

\begin{abstract}
This article considers how the decisions of the UK government, following the Brexit referendum, may impact on higher education in Africa. Ghana and South Africa are the two countries chosen to exemplify the claim that academic staff in African higher education will lose opportunities to acquire experience in British universities. Academic mobility between Africa and the UK is expected to fall significantly following Brexit.
\end{abstract}

\section{Introduction}

Africa and the EU have strong ties. Their current relations are based on the 2000 Cotonou Agreement with African, Caribbean and Pacific (ACP) countries which grew out of the 1975 Lomé Convention. More recently the Joint Africa EU Strategy (JAES) adopted in Lisbon in 2007 (European Union 2016a) clarifies the relationship. This strategy encompasses the Africa-EU Partnership and seeks to contribute to strengthening links between the parties in the field of higher education (HE) through building high-quality tertiary capacity via networking, increasing the mobility of students and scholars, and promoting institutional support and innovation (European Commission 2007).

The EU's role in supporting African HE, at the continental level, is important to Africa and to those who care about the future of the continent. The EU is spending 1.4 billion Euros on educational programmes in Africa from 2014 to 2020 (Council of the European Union 2017). The bloc is the main financier of the African Higher Education Harmonisation Tuning initiative aimed at addressing key skills and competences for employability, ensuring transparency of curricula, the development of learning outcomes and quality assurance (European Commission 2007). The EU is also the bankroller of the Pan-Africa University (PAU), a network of high-quality African universities that provides opportunities for advanced graduate training and postgraduate research to high-performing African students established in these regional hubs namely Algeria, Cameroon, Kenya and Nigeria with one still to be established in Southern Africa. Furthermore, the prestigious academic mobility programme involving a network of 15 universities and 120 partners from African countries dubbed the 'Nyerere Programme' is sustained financially by the EU (European Commission 2007). Lastly, the EU supports academic mobility amongst HEIs (HE institutions) in Europe and Africa through programmes such as Erasmus Mundus, Tempus, EDULINK and the new Erasmus + programme (European Commission 2007). 
The EU's commitment to Africa's HE continues to intensify. The significance of this support and corporation was acknowledged in speeches by Professor Etienne Ehile, the secretary-general of Association of African Universities (AAU), the President of Ghana, His Excellency Nana Akufo-Addo, and Dr Beatrice Kharmati Njenga, Head of the Education Division in the Department of Human Resources, Science and Technology of the African Union Commission at the 5oth anniversary conference of the AAU held in Ghana in 2017.

The EU's support for Africa's HE sector goes beyond the continental commitments listed above. Apart from these continental projects, the EU has bilateral agreements with some individual African countries. Sub- Saharan African countries such as Ghana, Kenya and South Africa (SA) are examples of countries with special relationships with the EU as well as Britain. The EU is the largest investor in SA's economy (European Commission 2017a). Both parties have developed strong cooperative projects in education and training. Ghana's relationship with the EU came into existence after the first Lomé Convention in 1975 and since then the two parties have enjoyed fruitful cooperation (European Union 2016b). The EU is Kenya's most important development partner (European Union 2016c) and both are working to deepen the relationship. Ghana, Kenya and SA are also former colonies of Britain.

Looking at the relationships that exist between the EU, the UK and these Sub-African countries it is likely that Brexit will impact on Africa's HE. However, there seems to be a knowledge gap on the possible consequences of Brexit for African HE. This paper seeks to explore the possible consequences of Brexit for African HE. More specifically, the paper investigates the perceived impact of the Brexit through the lenses and experiences of experts and students from two African countries (Ghana and SA) that have had long-term partnerships with the UK.

\section{The implications of Brexit for HE in Ghana}

Brexit and how it might impact on Britain, EU and the global economy has been widely discussed but the implications for Ghana's HE system is yet to be part of the narrative. The UK's decision to withdraw from the EU has cast doubts over the partnerships between Ghanaian universities and the EU, and projects funded by EU which assist HE in Ghana. Though there is no cause for alarm in the short term, because there are conditions attached to deals, partnerships, projects or schemes operated by the EU until 2019, those with a lifespan going beyond 2019 will have to be negotiated.

The biggest concern of most Ghanaians is the effect Brexit may have on academic mobility projects funded by EU. Erasmus Mundus+ and Marie Curie are examples of scholarships and fellowships operated by the EU, meant to help beneficiaries acquire high-level skills, knowledge and varied experience to contribute to the sustainable development of their countries. These scholarships and fellowships are mostly hosted in Universities and research centres in Europe including those in Britain. Britain is home to some of the world's most powerful universities such as Oxford and Cambridge, University College London and London School of Economics and Political Science. Since 2004, 245 students and staff from Ghana have benefited from 
Erasmus+ scholarships (citifmonline.- com 2017). In addition, 16 Marie Curie fellowships were awarded to Ghanaians from 2007 to 2014 (European Commission 2016). As a former British colony, Ghana has strong historical, social, cultural, political and economic ties with Britain. For example, English Language is the medium of instruction for Ghana's education. In addition, Ghana's HE system bears some traces of the DNA of British Education. These conditions make British universities an attractive destination for Ghanaian beneficiaries of European Union funded scholarships and fellowships.

Although there is no available data on the number of Ghanaians who have received Erasmus Mundus and Marie Curie scholarships to study in British universities, Britain's exit from the EU will harm Ghanaian beneficiaries of EU funded scholarships and fellowships. It is likely that future Ghanaian awardees of Erasmus +, Marie Curie and other EU fellowships after 2019 will not be hosted by a British university. Apart from the language barrier these Ghanaian beneficiaries may encounter in studying in EU countries, which is likely to hinder effective learning, the beneficiaries will be denied the quality of experience, the knowledge and the skills, they could have gained from studying in UK universities. The beneficiaries will also be denied the opportunity to interact and network with international scholars in their fields of study based in the UK.

Brexit will see UK universities obtaining zero revenue from EU programmes and this is likely to result in increased tuition fees so that universities compensate themselves for the loss. Already, UK universities charge high international tuition fees compared to their peers in the EU. However, they are perceived to offer quality education and are deemed prestigious. The UK is the preferred study destination for most self-sponsored and sponsored Ghanaian students. It is likely that international students' tuition fees will increase after Brexit. When this happens, most Ghanaian students may opt for academic programmes in universities in other European countries other than Britain. The likely impact could be that most Ghanaians will be denied the chance of benefiting from quality British HE.

Resistance to migration influenced the referendum outcome on 23 June 2016. Supporters of Brexit called for a significant reduction in the overall level of migration into the United Kingdom (Marginson 2017). Brexit seeks to introduce 'hostile visa regulations'. Already, Ghanaian students and academic staff seeking entry to Britain face stringent visa application process. It is expected that student and academic staff mobility between Ghana and Britain will plummet significantly post-Brexit.

The UK's withdrawal from the EU is likely to harm research and academic collaborations with Ghanaian universities. UK universities are popular for their cutting-edge research discoveries. Currently, they obtain $£ 1$ billion yearly from Horizon 2020, the biggest EU Research and Innovation programme ever with nearly $€ 80$ billion of funding available over seven years from 2014 to 2020 (European Commission 2017b). This revenue enables British academics to participate in research and organise academic events and activities with their colleagues globally, including those in Ghanaian universities. With the UK leaving the EU, Ghanaian universities will not be 
able to undertake joint research projects funded by the EU with academics in UK universities. This may impact negatively on the quality and quantity of research by Ghanaian universities. Furthermore, the impact factor of publications from research findings by Ghanaian academics may suffer because internationally co-authored papers have a greater impact. However, it can also be argued that Brexit will have some positive impacts on Ghana's HE systems and its stakeholders. British aid funds channelled through the European Development Fund (EDF) may cease after 2019. The UK's contribution to EDF currently stands at $£ 409$ million $(\$ 585$ million) (Sow and Sy 2016). This accounts for $14.8 \%$ of the total contributions to the fund. Brexit means EDF will be starved of this financial resource. It is likely that these funds will be directly channelled via British Organisations such as DfID and may have a greater impact on HE in Ghana.

There may be compensations. Britain's active participation in the European Union seems to have affected its commitment to the scholarships and fellowships it offered students and academics from its former colonies such as Ghana. With Britain leaving the European Union, there is the possibility that Britain will commit more resources to scholarships such as Commonwealth and Chevening. This will allow more students and academics from Ghana to benefit from scholarships and fellowships funded by Britain.

\section{The implications of Brexit for HE in SA}

The EU is SA's most important development partner, providing 70\% of all external assistance funds: $25 \%$ from the European Commission, 20\% from the European Investment Bank (EIB) and 25\% from the EU Member States (European Commission 2017c). Both parties further strengthened their relationship in 2007 with the signing of a Strategic Partnership, 1 of the 10 in the World and the only 1 the EU has with an African country (European Commission 2017c). The Development Cooperation Instrument that capture this new relationship confirms $\mathrm{HE}$ as a major focus of the collaboration. By the end of 2019 the UK will not legally be part of the EU, nor a signatory to the EU's numerous agreements and collaborations (McClean 2017). Brexit is bound to impact on South African HE.

The EU and SA have numerous programmes that provide opportunities for international cooperation in HE. Amongst them are academic mobility projects such as Erasmus+, EuropeanSouth African programme in Tuning for Regional Needs in HE (EU- SATURN), EUSA_ID, Mobilité Universitaire en Afrique (MOUNAF), The Alliance Universities International Credit Mobility programme (Action KA107), a European and South African Partnership on Heritage and Past+ (AESOP+) and the International Science Promoting Innovation and entrepreneurship (INSPIRE) (Erasmus Mundus 2017a, 2017b). These initiatives give South African Masters', doctoral students and staff beneficiaries the opportunity to study and research in European universities as well give European beneficiaries the chance to do same in South African universities. For example, EUSA_ID since its inception in 2014 has assisted 84 individuals (18 European, 66 South African) covering Masters' students, PhD candidates and staff (Erasmus Mundus 2017a). Data on beneficiaries of other mobility schemes are not readily available except Erasmus Mundus. 
Erasmus Mundus is part of a bigger picture of EU-SA relationships in the field of $\mathrm{HE}$ and training (Mail \& Guardian 2015). Between 2010 and 2014, the EU allocated €22-million (approximately R300-million) to support South African beneficiaries of Erasmus Mundus. The EU has

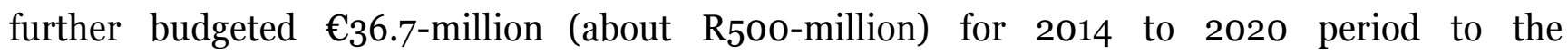
Erasmus+ programme which will succeed Erasmus Mundus actions (Mail \& Guardian 2015). In SA, Erasmus+ will specifically focus on capacity building for HE. It aims at supporting the modernisation, accessibility and internationalisation of South African HE. For example, HEIs can secure funding for joint projects, modernise and disseminate new curricula, teaching methods and materials, as well as to enhance quality assurance and governance (Mail \& Guardian 2015). Erasmus+ will also support credit mobility through Erasmus postgraduate programmes, as well as staff mobility (Mail \& Guardian 2015). This will enable students to study up to 12 months abroad at the host university, ensuring that all grades and credits obtained at bachelor's, master's or doctoral level are recognised by the home university (Mail \& Guardian 2015). Up to the time of writing, 537 South Africans are known to have benefited from Erasmus Mundus programme allocations (Mail \& Guardian 2015).

Erasmus Mundus schemes serve additional purposes in SA. They are used by the Department of Higher Education and Training (DHET) to respond to specific South African challenges and transformation objectives such as equity and quality within HE (Mail \& Guardian 2015). For example, the scheme requires HEIs participating in Erasmus to demonstrate their strategies to address gender balance and diversity, and to ensure the participation of historically disadvantaged institutions and universities of technology (Mail \& Guardian 2015).

Academic mobility programmes seem to have had positive impacts on HEIs, staff and students. The programme contributes to the strengthening of international offices of most participating universities. Beneficiaries of EU mobility schemes in South Africa are known to have acquired transversal skills through their training hence enhancing their employability.

EU academic mobility programmes create relationships that benefit staff and students and link SA and EU universities together but some of these opportunities may be lost when Brexit comes into effect. The threat to these academic mobility schemes is that the agreements establishing them might need to be renegotiated as Britain leaves the EU. It is likely that some of these schemes will not be attractive after the agreements establishing them are redrafted. Funding for these projects may dwindle post-Brexit because EU will not receive any revenue from the British government. This may shorten the lifespan of some schemes and threaten the existence of others as well. The effects of these outcomes are that academic mobility between the EU and SA will reduce drastically. British staff and students who preferred South African universities to host them will be exempted from the programme by 2019. Similarly, South African staff and students who will be awarded EU-funded scholarships and fellowships cannot opt to pursue their programmes in British Universities. The duration to be taken by SA to address equity and quality in its HE system may lengthen whilst traversal skills may elude some SA university graduates. 
SA and the EU collaborate on other educational initiatives. SA's education sector normally receives budget support from the EU. Since 2009, the budget support the SA government receives from the EU through the Primary Education Sector Policy Support Programme (SPSP) has assisted her to increase the number of public universities involved in training teachers for the early grades and increase students enrolled in such programmes (European Commission 2017c). With Britain being a major contributor (14.8\%) to the EDF (Sow and Sy 2016), where funds are usually drawn to support EU aids in developing countries, her exit from the bloc will deprive EDF of this contribution. This may negatively impact on EU's support to developing nations including SA's SPSP. Apart from preventing more South African universities to be involved in the training of early childhood teachers, prospective students for this programme may not gain entry due to lack of funding.

SA and the EU have track records of cooperation on research. Research collaboration between SA and the EU was established under the Science and Technology Cooperation Agreement concluded in 1996 and came into force in November 1997 (Times Higher Education 2016). It aims at promoting mutual learning and sharing the results of knowledge generation programmes, supporting researcher mobility to gain experience in top EU institutes and encouraging South African industry involvement to promote innovation and collaboration with academia.

SA and EU research collaborations include, but are not limited to, marine ecosystems, climate, food and energy systems, earth observation, and global health research, bio-economy, water and waste management partnerships (Times Higher Education 2016). SA and the EU research collaborations are pursued through various initiatives. Research initiatives such as Marie Curie Fellowship and the European South African Science and Technology Advancement Programme (ESASTAP) foster appropriate partnerships between EU and SA researchers and market SA research organisations and universities as destinations for European researchers to spend time (Times Higher Education 2016).

Brexit undoubtedly has the potential to de-stabilise this collaboration. Britain is a key player of Horizon 2020, EU's flagship research initiative. It can boast of quality research universities, centres and researchers. Britain is a big contributor of financial resource for research infrastructure development in Europe. With Britain's decision to leave the EU, research collaboration between EU and SA will have to be renegotiated. Funding for research initiatives between EU and SA may dwindle. It may not be possible for SA HEIs and researchers to collaborate with HEIs in the UK and their colleagues. Overall, this can impact negatively on the quality and quantity of research in SA HEIs.

\section{Conclusion}

The UK's decision to withdraw from the EU after more than four decades has major implications not only for the British economy but it will also affect the relationship that the EU has with developing countries such as Ghana and SA. It is expected that the implementation of Brexit, 
whether this be hard or soft, will impact on the HE systems of these countries, and Kenya as well. Of particular concern is the impact Brexit will have on the EU-funded academic mobility schemes, research collaboration and EU financial support to the HE systems of these countries. It is likely that Brexit will result in lack of funding for these schemes. Conditions of these schemes may also be renegotiated. The outcome will be that the lifespan of some of these schemes will be shortened whilst others will collapse post-Brexit.

Academic mobility between EU and these countries will plummet drastically. Beneficiaries of these schemes may be prevented from acquiring experiences from British universities and partnering with British academics. Research collaboration between EU and African countries is likely to be impacted negatively and EU funding support for African HE will probably decline in real terms. This notwithstanding, the HE systems of these countries may see positive signals PostBrexit. Britain may redesign its aid schemes to these countries to make them effective. It may also revive the Commonwealth as a way of filling the vacuum that the exit from EU may create. 


\section{References}

citifmonline.com. 2017. "Ghanaian Students Get EU Scholarships." Accessed October 3 , 2017. http:// citifmonline.com/2017/07/28/20-ghanaian-students-get- euscholarships/.

Council of the European Union. 2017. "5th African Union-EU Summit 29-30/11/2017: Main Results-EU and Africa in Numbers." Accessed December 1, 2017. http://www.consilium.europa.eu/en/meetings/international-summit/2017/11/29-30/.

Erasmus Mundus. 2017a. "Capacity Building in Higher Education for an Improved Cooperation Between the EU and SA in the Field of Development Studies." Accessed December 27, 2017. http://www.eusa-id.eu/.

Erasmus Mundus. 2017b. "EU-SATURN: The European Scholarship for South Africans." Accessed November 10, 2017. http://www.eu-saturn.eu/about-eusaturn.

European Commission. 2007. "The Africa-EU Strategic Partnership." Accessed November 23, 2017. https://ec. europa.eu/education/policy/international-cooperation/africa_en.

European Commission. 2016. "FP7-PEOPLE Marie Curie Actions: Country fact sheet: Ghana." Accessed November 30, 2017. https://ec.europa.eu/assets/eac/msca/fundedprojects/statistics/non-eu/marie-curieactions-country- fiche-gh_en.pdf.

European Commission. 2017a. "Countries and Regions: South Africa." Accessed December 23, 2017. http://ec.europa.eu/trade/policy/countries-andregions/countries/south-africa/.

European Commission. 2017b. "Horizon 2020: The EU Framework Programme for Research and Innovation." Accessed December 20, 2017. https://ec.europa.eu/ programmes/horizon2020/en/what-horizon-2020.

European Commission. 2017c. "International Cooperation and Development: Building Partnerships for Change in Developing Countries - South Africa.” Accessed December 1, 2017. https://ec.europa.eu/europeaid/countries/south- africa_en.

European Union. 2016a. "Africa and EU. Accessed October 30, 2017." https://eeas.europa.eu/headquarters/headquartershomepage_en/328/Africa\%20and\%20the\%20EU.

European Union. 2016b. "External Action: Ghana and the EU." Accessed December 1, 2017. https://eeas.europa.eu/ headquarters/headquarters-homepage/1247/ghana-and- eu_da.

European Union. 2016c. "Kenya and the EU." Accessed December 24, 2017. https://eeas.europa.eu/delegations/ kenya_en/1377/Kenya\%20and\%20the\%20EU.

Mail \& Guardian. 2015. "Special Reports: International Collaboration Through Higher Education." Accessed November 30, 2017. https://mg.co.za/article/2015-022806- oointernational-collaboration-through-higher-education. 
Marginson, S. 2017. "Brexit: Challenges for Universities in Hard Times." International 30 Higher Education Winter 88: 8-10.

McClean, P. 2017. "After Brexit: The UK Will Need to Renegotiate At Least 759 Treaties." Accessed November 1, 2017. https://www.ft.com/content/f1435a8e-372b- 11e7-bce49023 f8cofd2e.

Sow, M., and A. Sy. 2016. "The Brexit: What implications for Africa? Africa in Focus." Accessed December 23, 2017. https://www.brookings.edu/blog/africa-in36focus/2016/ 06/21/thebrexit-what-implications-for-africa/.

Times Higher Education. 2016. "South Africa and EU aim to promote closer collaboration in research." Accessed December 20, 2017. https://www.timeshighereducation. com/news/south-africa-and-eu-aim-to-promotecloser-collaboration-article\#surveyanswer. 